\title{
Plasma ranitidine concentrations after intravenous administration in normal volunteers and haemodialysis patients
}

\author{
A. P. ROBERTS \\ B.Sc., Ph.D., M.I.Biol. \\ G. T. DIXON† \\ B.Sc., Ph.D., M.B.B.S.
}

C. HARRISON $\dagger$

F.I.M.L.S.

J. R. CURTIS*

M.D., F.R.C.P.

\author{
Departments of Microbiology and Medicine, \\ Charing Cross Hospital Medical School, London W6 8RF and \\ †Glaxo Group Research Ltd, Ware, Herts SGI2 ODJ
}

\begin{abstract}
Summary
A comparison was made of the plasma concentrations of ranitidine base in 12 normal volunteers after the administration of $100 \mathrm{mg}$ intravenously and in 6 patients with terminal renal failure after $40 \mathrm{mg}$ intravenously off and then during haemodialysis. The plasma ranitidine concentrations were determined by radioimmunoassay. The results suggest that reduced elimination of the drug occurs in patients with severe renal failure and that there is significant removal of the drug during haemodialysis. It is suggested that dosage reduction is advisable in patients with severe renal failure and a suitable schedule for such patients is described.
\end{abstract}

KEY WORDS: ranitidine, haemodialysis, $\mathrm{H}_{2}$-receptor.

\section{Introduction}

Ranitidine is a relatively new $\mathrm{H}_{2}$-receptor antagonist which is highly water soluble with a $\log P$ value of 0.2 and $\mathrm{pKa}$ values of 8.2 and 2.7 . A mean urinary excretion, after intravenous injection, of $68.2 \%$ as unchanged drug together with less than $10 \%$ as the $\mathrm{N}$ oxide, desmethyl derivative and $\mathrm{S}$-oxide during the first $24 \mathrm{hr}$ has been reported in normal volunteers (Carey, Martin and Owen, 1981). The elimination half-life of ranitidine after intravenous injection ranged from 110-248 $\mathrm{min}$ and the mean renal clearance value was $512 \mathrm{ml} / \mathrm{min}$ in normal subjects indicating extensive tubular excretion of ranitidine in addition to glomerular filtration (Carey et al., 1981). Reduced elimination of the drug was therefore anticipated in patients with severe renal failure.

\section{Material and methods}

\section{Subjects}

Twelve normal volunteers and six patients with terminal renal failure were studied. The endogenous creatinine clearance in the 6 patients was less than 5 $\mathrm{ml} / \mathrm{min}$ and all 6 were undergoing regular haemodialysis treatment using disposable Gambro Dialysers for 6-8 hr twice weekly. The normal volunteers and the patients all gave their informed consent to the study and the experimental protocol had been approved by the ethical subcommittee of Charing Cross Hospital.

\section{Procedures}

Each normal subject was given $100 \mathrm{mg}$ of ranitidine base intravenously (i.v.) over $1 \mathrm{~min}$ and blood samples obtained through an indwelling i.v. needle at $1,2,3,4,5$ and $12 \mathrm{hr}$.

The patients with renal failure were each studied on two separate occasions, once on a non-dialysis day and then on another occasion during haemodialysis. On each occasion, $40 \mathrm{mg}$ of ranitidine base was given i.v. over $1 \mathrm{~min}$ and blood samples obtained at 1,2,3, 4 and $5 \mathrm{hr}$. In 4 patients during the non-dialysis study, a final blood sample was taken $24 \mathrm{hr}$ after the dose. During the haemodialysis study, the $40 \mathrm{mg}$ of ranitidine base was given at the start of haemodialysis.

The plasma ranitidine concentrations were determined by radioimmunoassay (Jenner et al., 1981). Statistical analysis was by Wilcoxon sum of ranks test of difference and signed ranks test of difference. 
TABLE 1. Plasma ranitidine base concentrations ( $\mathrm{ng} / \mathrm{ml}$ ) after $100 \mathrm{mg}$ i.v. (normals) and $40 \mathrm{mg}$ i.v. (patients)

\begin{tabular}{|c|c|c|c|c|c|c|c|c|c|}
\hline & & & \multicolumn{7}{|c|}{ Time of sample collection $(\mathrm{hr})$} \\
\hline & & & 1 & 2 & 3 & 4 & 5 & 12 & 24 \\
\hline \multirow{2}{*}{ Normal subjects (A) } & \multirow{4}{*}{ Off dialysis (B) } & Mean & 557 & 389 & 272 & 190 & 136 & 20 & \\
\hline & & s.d. & 74 & 46 & 53 & 32 & 30 & 8 & \\
\hline \multirow{7}{*}{ Patients } & & Mean & 330 & 268 & 237 & 208 & 199 & & $35^{*}$ \\
\hline & & s.d. & 88 & 72 & 79 & 71 & 87 & & 13 \\
\hline & \multirow{5}{*}{ On dialysis $(\mathrm{C})$} & Mean & 276 & 217 & 181 & 151 & 132 & & \\
\hline & & s.d. & 44 & 33 & 32 & 25 & 34 & & \\
\hline & & $A \wedge B$ & $P<0.01$ & $P<0.01$ & N.S. & N.S. & N.S. & & \\
\hline & & AvC & $P<0.01$ & $P<0.01$ & $P<0.01$ & $P<0.05$ & N.S. & & \\
\hline & & $\mathrm{B} u \mathrm{C}$ & N.S. & $P<0.05$ & $P<0.05$ & $P<0.05$ & $P<0.05$ & & \\
\hline
\end{tabular}

$* n=4$.

N.S.: not significant.

\section{Results}

Table 1 shows the mean plasma ranitidine concentrations together with the standard deviations (s.d.) in normals and patients and also the results of the statistical evaluations. Figure 1 shows the mean values +2 s.d. in normals and patients.

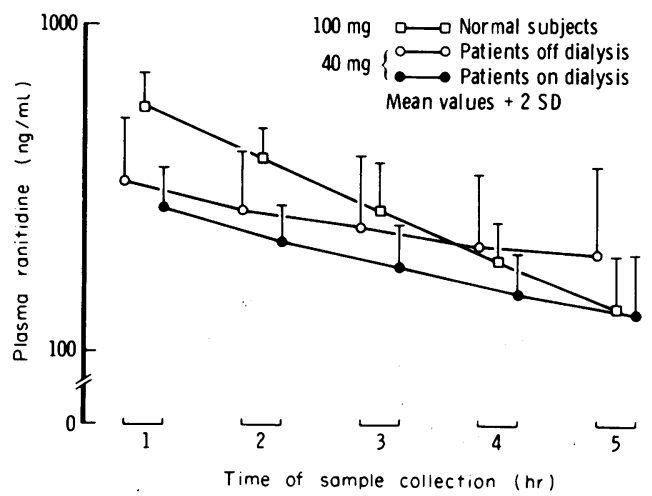

FIG. 1. Mean plasma ranitidine base concentrations +2 s.d. in $\mathrm{ng} / \mathrm{ml}$ after $100 \mathrm{mg}$ ranitidine base intravenously in normal subjects: and after $40 \mathrm{mg}$ intravenously in dialysis patients both off and on dialysis.

\section{Comparison of normal volunteers with renal failure} patients during a non-dialysis period

The mean plasma ranitidine concentrations were significantly higher in the normal volunteers at 1 and $2 \mathrm{hr}$ but there were no significant differences at 3,4 and $5 \mathrm{hr}$. At 4 and $5 \mathrm{hr}$, the mean values were in fact higher in the renal failure patients but not significantly so. In the 4 patients in whom 24-hr samples were obtained, the mean value at $24 \mathrm{hr}$ was significantly higher than the mean value at $12 \mathrm{hr}$ in the normal volunteers $(P<0.05)$.

Comparison of normal volunteers with renal failure patients during haemodialysis

The mean plasma ranitidine concentrations in the normal volunteers were significantly higher than ib the patients during haemodialysis up to $4 \mathrm{hr}$, but at $\mathrm{hr}$ the levels were almost identical.

\section{Comparison of renal failure patients on a non-dialysio period and during haemodialysis}

After the first hour, the mean plasma ranitidine concentrations were significantly lower during hae modialysis than the values obtained in the same patients in a non-dialysis period.

\section{Discussion}

In this study, the results suggest that reduceed elimination of ranitidine occurs in patients wit severe renal failure. Thus the mean concentration after the first $2 \mathrm{hr}$ in the renal failure patients during a non-dialysis period and after only a $40 \mathrm{mg}$ dose of ranitidine base were higher although not significantl $\vec{b}$ so than in the normal volunteers given $100 \mathrm{mg}$ of ranitidine base. In addition the 4 patients in whom 24 $\mathrm{hr}$ samples were obtained during the non-dialysi study had a mean concentration at $24 \mathrm{hr}$ which was significantly higher than the mean concentration ap. $12 \mathrm{hr}$ in the normal volunteers.

The comparison of ranitidine concentrations in the patients during a non-dialysis period and during haemodialysis suggests that significant amounts of ranitidine are removed by haemodialysis. After $1 \mathrm{hr}$ 음 the mean plasma ranitidine concentrations were alb significantly lower during haemodialysis. This find을. ing was also to be anticipated in view of the relativelyn low molecular weight $(350.87$ daltons) and smalp degree of protein-binding $(15 \pm 3 \%)$ of the drug.

Some attempts at correlation between plasmaw concentrations of ranitidine and pharmacologicap effects have been made and 50\% inhibition of pentagastrin-induced acid secretion has beeñ achieved at a mean plasma ranitidine concentration ${ }^{5}$ of $93.6 \mathrm{ng} / \mathrm{ml}$ (range 48-125) in patients witho duodenal ulcer (Peden, Saunders and Wormsley웅 1979; Peden et al., 1979). With this in mind and with 
the results of the present study, it is tentatively suggested that some dosage reduction can be recommended in patients with terminal renal failure. A dose of $40 \mathrm{mg}$ ranitidine base i.v. every $12 \mathrm{hr}$ would seem to be adequate with an additional dose of $40 \mathrm{mg}$ at the end of each dialysis.

\section{Acknowledgments}

Thanks are due to Sister Margaret Greatbatch and the Nursing Staff of the Renal Unit, Charing Cross Hospital who assisted with collection of some of the samples and to Mrs R. Thornley for processing of the blood samples.

\section{References}

Carey, P.F., Martin, L.E. \& OWen, P.E. (1981) Determination of ranitidine and its metabolites in human urine by reversedphase ion-pair high performance liquid chromatography. Journal of Chromatography, 225, 161.

JenNer, W.N., Martin, L.E., Willoughby, B.A. \& Fellows, I. (1981) The development of a radioimmunoassay for ranitidine in biological fluids. Life Sciences, 28, 1323.

Peden, N.R., Richards, D.A., Saunders, J.H.B. \& Wormsley, K.G. (1979) Pharmacologically effective plasma concentrations of ranitidine. Lancet, ii, 199.

PEDEN, N.R., SAUNDERS, J.H.B. \& WormsLey, K.G. (1979) Inhibition of pentagastrin-stimulated and nocturnal gastric secretion by ranitidine. A new $\mathrm{H}_{2}$-receptor antagonist. Lancet, i, 690.

(Accepted 11 May 1982) 